\title{
PSYCHOPHYSIOLOGICAL FEATURES OF MIDDLE-SCHOOL AGE PUPILS WITH IMPAIRED MENTAL DEVELOPMENT
}

\section{Yakovleva S. D.}

\section{INTRODUCTION}

There are significant differences as for occurrence of mental retardation cases in different countries and even in certain regions of one country. The frequency of mental retardation cases in economically developed countries (Japan, USA, France, Germany, Italy, etc.) is 3\% of the population independently from the age, it is $15 \%$ in economically underdeveloped countries (Latin America, Asian countries, etc.), and 1\% in Russia. The reasons for such differences in data includes: patients' diagnosis levels, different criteria for mental retardation diagnosis, as well as specifics of the culture in some societies and, therefore, the corresponding educational systems. According to A.A. Churkin (1997), $0.47 \%$ of the population have mild forms of mental retardation. According to V.V. Voronkova (1999), 70-80\% are children with mild forms of intellectual disabilities. At the same time, according to scientists, all available data are underestimated ${ }^{1}$.

The main goal of special education pedagogues is to support socialization of children with impaired mental development. During corrective work, it is necessary to take into account the peculiarities of mental and physical processes characteristics for children with impaired intelligence, which in turn requires knowledge of mental working capacities and fatigues of such children ${ }^{2}$.

Today, research on functional capabilities of mentally impaired children and, especially, adolescents (because the puberty period is important for the further development and socialization), under mental workload attract general interest. Revealing of the mechanism of

1 Яковлева С.Д. Нейрофизиологические основы деятельности детей с интеллектуальными отклонениями в развитии. Современное направление теоретических и прикладных исследований 2014 : сб. науч. трудов SWorld. 2014. Том 15. C. 84-93.

${ }^{2}$ Ibid. 
children's adaptation to learning and determination of their working ability recovery rate after fatigue; determination of workload thresholds for fatigue appearance in relations to age, physical and mental characteristics, as well as typological features of higher nervous functions are the main areas of research on mentally impaired pupils' fatigue processes.

This work purpose is to reveal the typological features of the higher nervous activity of middle-school age adolescents with impaired mental development and to determine their influence on their workability and fatigue.

In accordance with the research purpose, the following tasks were identified: fatigues;

1) to determine the psycho-physiological criteria influencing

2) to diagnose states of mental fatigues of mentally impaired pupils of middle-school age during their learning;

3) to show the relations between mentally impaired pupils' mental processes and their learning capabilities.

\section{Theoretical foundations of psychophysiological features of pupils with impaired mental development}

There are two large groups of etiological factors of mental disorders - exogenous and endogenous. Close relations exists between exogenous-social and endogenous-biological factor ${ }^{3}$.

Pathological heredity, some somatic diseases and auto intoxication belong to endogenous factors, which determine a degree of intellectual incapacity. Some infections affecting a child's development in the early years of life are exogenous factors. Some of infectious diseases (encephalitis, meningitis, poliomyelitis, measles, flu, etc.), as well as intoxication and brain tumours can cause developmental abnormalities.

A separate group of children with impaired mental development are children with oligophrenia. Oligophrenia is always caused by brain damage and, consequently, it is accompanied by disturbances in cognitive, emotional and volitional spheres. These disorders at oligophrenia are usually persistent.

${ }^{3}$ Синев В.Н. Коррекция интеллектуальных нарушений у учащихся вспомогательной школы : автореф. дис. ... докт. пед. наук : 13.00.03. 1988. 45 с. 
The external and internal environment can either promote or hinder disorder development. Some conditions reduce the body protective properties and, thus, increase influence of the main cause; other conditions mobilize the protective properties and weaken negative effects. Abnormalities of the mental development basis also determine its peculiarity. L.V. Zankov has proved that mental retardation is a general insufficiency that covers the whole psyche. Psychological studies have shown that not only higher processes of thinking (abstraction, established causal relations), but also all other mental processes and properties of mentally impaired children are deeply specific. These peculiarities are manifested already at the early developmental stages. Consequently, the psyche of children with mental disorders is abnormal in its very basis, and therefore such children cannot be considered as "ungifted", they are abnormal children ${ }^{4}$.

Mentally retarded people are characterized by underdevelopment of cognitive interests, which is expressed in the fact that they are less interested in knowledge acquisition in comparison with their peers with normative development. They have elements of underdevelopment at all stages of cognitive processes. As a result, these children receive incomplete, even sometimes distorted, notions on the surrounding world. At mental underdevelopment, there are violations of perception, especially of for perception generalization, its pace. Children with disordered intelligence require much more time to perceive material, because they have difficulties in selection of main parts and establishment of internal links between parts. Mental retardation is characterized by difficulties in perception of space and time, which prevents such children form orienting in the environment.

Perception is inextricably linked with thinking, which is the main tool of cognition in the form of such operations as analysis, synthesis, comparison, generalization, abstraction. All these operations are not sufficiently formed at mentally impaired children and have peculiar features, namely: analyzing objects, such children distinguish only general properties of the objects but not their individual characteristics; because of the analysis imperfection, they have difficulties with synthesis. A distinctive feature of mentally retarded children's thinking is non-criticality, their inability to evaluate independently their work.

\footnotetext{
${ }^{4}$ Занков Л.В. Обучение и развитие. Москва: Педагогика, 1975. 143 с.
} 
Educational material perception and comprehension by children are inextricably linked with peculiarities of their memory. Mentally impaired children better memorize external, random signs, while hardly aware and memorize internal logical connections. Arbitrary memorization is formed later in cases of impaired mental development in comparison with normative development. Memory weakness is manifested not only in difficulties at information obtaining and storing, but also at its reproduction. Because a logic of events is not understood, their reproduction is unsystematic. The greatest difficulty is in reproduction of verbal material, since mediated semantic memory is not accessible to the mentally impaired people. Undifferentiated fragmentation, image assimilation and other violations of perception affect negatively cognitive development. Violations of higher nervous activity, underdevelopment of mental processes are the cause of some specific features of mentally impaired children ${ }^{5}$.

As a result of general psychological underdevelopment, as well as limited needs and interests, mentally impaired pupils come to tasks formally. Faced with difficulties and obstacles, such pupils "slip" away from the way of task fulfilling and begin to do such actions and operations that divert them from the primary goal ${ }^{6}$.

The determination of the age-specific peculiarities of oligophrenic children's mental functioning is necessary for characterization of their cognitive activities and the diagnosis of mental developmental disorders.

New conditional connections, especially complex, are formed at mentally impaired children much slower than that of children with normative development. This weakness of the cerebral cortex closing function is manifested in the complicated formation of new, especially complex, conditional connections; this is the most important feature of children's higher nervous activity. This explains the extremely slow pace of mentally impaired children's learning ${ }^{7}$.

Functional state of mentally impaired children's cortex is changed. These changes in cell function are manifested in the fact that the processes of excitation and active internal inhibition become weaker.

${ }^{5}$ Синев В.Н. Коррекция интеллектуальных нарушений у учащихся вспомогательной школы : автореф. дис. ... докт. пед. наук : 13.00.03. 1988. 45 с.

6 Микадзе Ю.В. Нейропсихология детского возраста : учеб. пособ. СанктПетербург, 2008. 288 с.

7 Лурия А.Р. Высшие корковые функции человека. Санкт-Петербург, 2008. 624 с. 
The weakness of the excitation process results in poor interlocking of new conditional connections, and the weakness of active internal inhibition causes poor quality of differentiations. At various brain damages, weakening of one of the nervous processes - excitation or inhibition - prevails ${ }^{8}$.

Deterioration of the cerebral cortex functional state is also manifested in the fact that the nerve cells "working capacity" is reduced and they fall into the state of protective inhibition even after a small load ("phase" states, according to I.Pavlov). The mental working capacity is formed as a dynamic system of conditioned reflexes, which can be stored for a long time, but can be inhibited. Close interactions of different inhibition types support the biological expediency of behaviour, the plasticity of conditioned reflexes?

Knowledge of the phase state mechanism explains the well-known fact of significant variations in mental retardation degrees of children in special-need schools.

Many researchers (M.S. Pevzner, V.I. Lubovsky) mark, among the features of higher nervous activity of children with impaired intelligence, a distinct deceleration. Development of new conditional connection is dramatically slowed down. V.I.Lubovsky says that strong verbal connections are especially inert ones. This violation is linked with the underdevelopment of the second signalling system ${ }^{10}$.

Thus, from all the above, we can conclude that the main factors of oligophrenic children's mental working capacity are: the psychological factors (insufficient learning motivational), the physiological factors (the weakness of the excitation and inhibition processes, their inertia, the tendency to frequent protective inhibition) and the underdevelopment of the second signalling system.

An experimental study was carried out with middle-school age pupils having impaired mental development in order to understand the state of their psychophysiological systems.

${ }^{8}$ Макаренко М. В., Лизогуб В.С. Онтогенез психологічних функцій людини. Черкаси: Верикаль, видавець ПП Кандич С.Г., 2011. 256 с.

9 Павлов И. П. Общие типы высшей нервной деятельности животных и человека. Полное собрание сочинений. Академия наук СССР. 2-е изд., доп. Москва: Л. : Изд-во АН СССР, 1951. Т. 3, кн. 2. С. 267-293.

${ }^{10}$ Певзнер М.С., Лубовський В.І. Динаміка розвитку дітей - олігофренів. // Спеціальна психологія. Тексти. Ч.1. Кам'янець-Подільський, 1999. - С. 36-54 


\section{Experimental study of psychological and physiological peculiarities of middle-aged school pupils with impaired mental development of various degrees}

2 groups of pupils were selected to solve the put forward tasks. The first group included middle-school age pupils Kherson special-need school No1 (general educational institution for children who need correction of their mental development because of its impairments), the 6th form (branch A - children with the mild form of oligophrenia), totally 36 pupils aged 12-14 years; some of them have somatic disorders. The group consisted mainly for girls $(75 \%)$. The majority of pupils $(50 \%)$ had diagnosis of oligophrenia of hereditary genesis, $33.3 \%$ of them had the etiology of mental developmental impairmenta of not cleared genesis, $8.33 \%$ has mental developmental disorders appeared as complications after diseases, 8,33\% had mental disorders because of brain tumours (neurofibromatosis). Children are not homogeneous by the time of diagnosis.

The second (control) group included mentally retarded pupils of the Kherson secondary school of I-II degree No 33 (general educational institution with inclusive education). The control group consisted of 32 pupils: 24 girls, 8 boys, $12-14$ years of age with diagnosis: mental retardation.

Mentally retarded pupils have delay in analysis and synthesis development, they are characterized by prolonged use of general terms, rather than special notions, their analysis remains less detailed. The disadvantages of analysis development affect negatively their synthesis; it longer remains less consistent and systematic ${ }^{11}$.

Because delayed formation of visual-image thinking and slow development of verbal speech, mentally retarded pupils have delay in verbal-logical thinking. This is manifested also in development of mental operations. The mental operations are the most general actions; they are organized in systems and are mutually agreed. The specified properties of mental operations are formed gradually. According to the study, all mental operations of mentally retarded pupils are formed later than that of pupils with normative development.

11 Яковлева С. Д. Нейрофизиологические основы деятельности детей с интеллектуальными отклонениями в развитии / С. Д. Яковлева // Современное направление теоретических и прикладных исследований 2014 : сб. науч. трудов SWorld. - 2014. - Том 15. - С. 84-93. 
We have defined the concept of fatigue in order to determine the corresponding state. Fatigue is temporary decrease of working capability under prolonged load influence. It arises as a result of an individual's internal resources exhaustion and inconsistencies in the work of the systems providing an activity. Fatigues has a variety of manifestations: in behaviour (decrease in labour productivity, decrease in speed and accuracy of work); physiological changes (difficulty of conditioned connection creation, increased inertia of nerve processes); psychological changes (decrease in sensitivity, attention deficit, disorders of memory and intellectual processes); violations of the emotional and motivational sphere. The specificity of fatigue manifestations depends on load types, action localization and time required to restore the optimal level of working capability.

Thus, fatigue processes are related very closely to an individual's nervous system properties and his/her psychological factors. Therefore, the following research methods were chosen that complement each other.

1. Examination of medical data that reflect somatic, neurological and psychopathological condition of learning. Examination of personal cases that indicate the time, circumstances and peculiarities of manifestation of examined pupils' disorders.

2. Observing over the examined pupils during lessons and nonschool hours, which allowed us to draw conclusions about their general level of motivation.

Determination of some characteristic peculiarities of behaviour and learning was done with Yu.Z.Gilbukh's scale (five-point scale of intensity of qualities), characterizing a general level of personality formation, as well as strength of nerve processes by subjective observations.

At the same stage, pupils were questioned to determine their learning motivation, which was carried out in writing, individually. After the questionnaire filling, pupils' levels of learning motivation were assessed (3 points for each first answer, 1point for the intermediate score, 0 point for the last one). Maximum score is 30 points. The higher the score is, the higher the learning motivation is. For convenience, the score assessments were transferred to levels: 25-30 points means that an individual's attitude towards him/herself as a pupil has been formed, high learning motivation; 20-24 points means that an individual's 
attitude towards him/herself as a pupil has been practically formed, a sufficient level; 15-19 points means positive attitude towards school, but non-academic aspects of the school are the most interesting, an average level; 10-14 points means that an individual's attitude towards him/herself as a pupil has not been formed, a below average low. Below 10 points means a negative attitude to school, low learning motivation.

3. Physiological examination of the nerve processes allows us to make a conclusion about the influence of an individual's higher nervous functions on his/her mental working capacity. In order to determine strength and mobility of the nervous processes, the computer version of the method created by N.V.Makarenko and A.E. Khilchenko was used. The method was chosen because:

- strength of the nervous processes is one of the main properties of the nervous system, which reflects the ability of the cerebral cortex cells to withstand, without transition into inhibition, either very strong or prolonged (albeit not strong) excitations. The opposite property - the nervous process weakness - characterizes inability of the nerve cells to withstand prolonged and concentrated excitation and inhibition;

- mobility of nervous processes is one of the primary properties of the nervous system, which characterizes the brain ability to respond quickly to changes in the environment. Mobility of nervous processes indicates the rate of appearance and termination of conditional connections.

Individual differences in the functions of perception, attention and thinking depend, to a large extent, on functional mobility of the nervous processes. Individuals with high and average mobility of the nervous processes, in contrast to those who are diagnosed with low mobility, are characterised by better perception and thinking, high skills of operations with spatial objects, quick attention concentration and switching. These mental functions are implemented with the same neurophysiologic mechanisms that provide the functional mobility of nerve processes. These mechanisms characterize the properties of higher nervous activities and are responsible for the individual characteristics of complex neurodynamic and psychomotor activities (O. R. Luria) ${ }^{12}$.

Information on functional mobility of the nervous processes is important for learning success prediction and development of individual

12 Лурия А.Р. Высшие корковые функции человека. Санкт-Петербург, 2008. 624 с. 
approaches to pupils. We estimated the cerebral cortex efficiency on the basis of errors made during the experimental task. The strength of the nervous system was evaluated by the following indicators:

$1.1 \ldots .10 .9 \%$ errors - very strong nervous processes;

$11,0 \ldots 15,9 \%$ errors - medium strength of nerve processes;

$16,0 \ldots 20,9 \%$ - weak variation of strong nervous processes;

$21,0 \ldots 25,9 \%$ - strong variation of weak nervous processes;

$26.0 \%$.. and more - weak nervous processes.

The experimental data that indicate maximum speed of stimuli presentations, at which tested individuals made no more than $5.5 \%$ of errors, were used as a qualitative index of nerve process mobility. For determination of actual nervous process mobility, we used recommendations suggested in this method: 110 frame / min. means the high level of functional mobility; $90 \ldots 100$ frames per minute means the average level; $70 . .80$ frame / min. means the below average level; and 60 frames / min means the low level.

According to the literature data analysing the higher nervous functions of children with mental disorder, the nervous process mobility is affected primarily. Therefore, this indicator should be taken into account at psychological corrective work and teaching of children with intellectual disabilities.

4. Dynamics of the maximum rate of upper limb movement indicates the nervous process strength. To diagnose, E.P.Ilyn's tapping test (a psychophysiological study) was chosen, which is based on the study of the nerve process mobility that indicates the reaction speed, the nervous system ability to perform a certain number of working cycles per time. Functional mobility of nerve processes characterizes an individual's quickest capability to perform a task, that is a rapid, alternate change of nervous system excitation and inhibition.

5 . The study of neuropsychological process states was supported by the psychological research method: E.Krepelin' method aimed at diagnostics of accuracy and working capability-fatigue. This is a "fill-inthe-blanks" method based on determination of attention volume, performance and accuracy.

Experimental study of the peculiarities of the psycho-physiological development of special-need school pupils took place in two stages.

At the first stage, documental information about each pupil was studied, including their medical cards and personal records. During 
investigation of pupils' medical and personal records, we found that most pupils of the 6th form of the special-need school had satisfactory physical health. At this stage, we performed observations and talked with the pupils to identify their learning motivation and pupils' behavioural characteristics, as shown in Table 1.

Quantitative indicators in Table 1 show that the pupils with impaired mental development perceive themselves as school pupils. At the age of 12-14 years, they already have formed rules of conduct in a classroom and at communications. But the average data of all indicators of the mentally retarded pupils are different from that of the pupils with impaired mental development. The following characteristics shows particularly noticeable differences: attitude to difficulties, behaviour, stress at task performance, general working capability. The resulting comparison is particularly well reflected in Diagram 1.

Table 1

\section{Behavioural indicators the studied groups according to Yu.Z.Gilbuh's table}

\begin{tabular}{|c|c|c|c|c|c|c|c|c|c|c|}
\hline \multirow[b]{2}{*}{ No } & \multirow[b]{2}{*}{$\begin{array}{l}\text { Respondent } \\
\text { groups }\end{array}$} & \multicolumn{9}{|c|}{ Indicators } \\
\hline & & 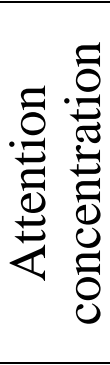 & 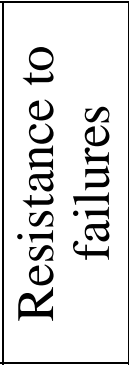 & 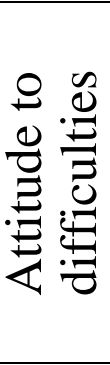 & 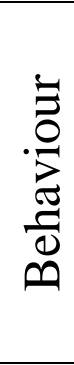 & 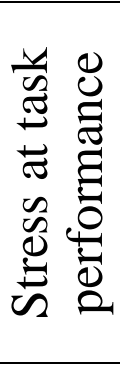 & 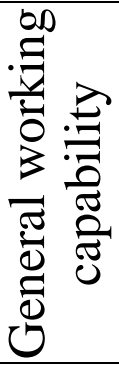 & 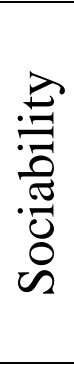 & 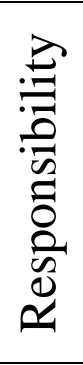 & 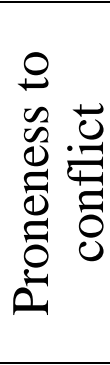 \\
\hline 1. & $\begin{array}{l}\text { pupils with } \\
\text { impaired } \\
\text { mental } \\
\text { development } \\
\text { (experimental } \\
\text { group) } \\
\mathrm{n}=36\end{array}$ & $\begin{array}{l}8 \\
0 \\
0 \\
H \\
\text { ते } \\
\text { ה }\end{array}$ & $\begin{array}{l}0 \\
0 \\
0 \\
+1 \\
\sigma\end{array}$ & $\begin{array}{l}\overline{0} \\
0 \\
H \\
\stackrel{1}{N} \\
\tilde{0}\end{array}$ & $\begin{array}{l}+ \\
8 \\
0 \\
0 \\
+1 \\
n \\
\sigma_{0} \\
8\end{array}$ & $\begin{array}{l}0 \\
0 \\
0 \\
+1 \\
\sigma \\
\sigma\end{array}$ & 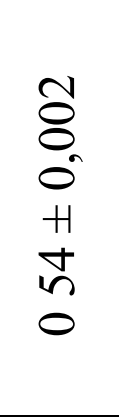 & \begin{tabular}{l}
8 \\
8 \\
0 \\
$H$ \\
$H$ \\
\multirow{2}{n}{} \\
\multirow{2}{*}{}
\end{tabular} & $\begin{array}{l}1 \\
0 \\
0 \\
+1 \\
8 \\
o \\
\text { i }\end{array}$ & $\begin{array}{l}2 \\
8 \\
0 \\
0 \\
+1 \\
0 \\
-1\end{array}$ \\
\hline 2. & $\begin{array}{l}\text { Pupils with } \\
\text { mental } \\
\text { retardation } \\
\text { (control } \\
\text { group) } \\
\mathrm{n}=32\end{array}$ & $\begin{array}{l}+ \\
0 \\
0 \\
H \\
n \\
n \\
n \\
n\end{array}$ & $\begin{array}{l}n \\
0 \\
0 \\
+ \\
n \\
n \\
m\end{array}$ & 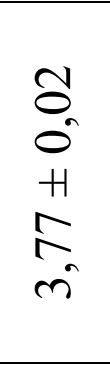 & $\begin{array}{l}2 \\
0 \\
0 \\
+ \\
\infty \\
\infty \\
\infty \\
\text { n. }\end{array}$ & $\begin{array}{l}\bar{\sigma} \\
0 \\
H \\
\text { ते } \\
\text { ñ } \\
\text { n. }\end{array}$ & $\begin{array}{l}0 \\
0 \\
0 \\
+ \\
0 \\
0 \\
0 \\
m\end{array}$ & 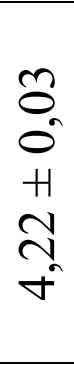 & 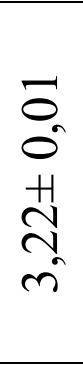 & $\begin{array}{l}\tilde{\sigma} \\
0 \\
+1 \\
\text { ते } \\
\text { m. }\end{array}$ \\
\hline
\end{tabular}


Quantitative indicators in Table 1 show that the pupils with impaired mental development perceive themselves as school pupils. At the age of 12-14 years, they already have formed rules of conduct in a classroom and at communications. But the average data of all indicators of the mentally retarded pupils are different from that of the pupils with impaired mental development. The following characteristics shows particularly noticeable differences: attitude to difficulties, behaviour, stress at task performance, general working capability. The resulting comparison is particularly well reflected in Diagram 1.

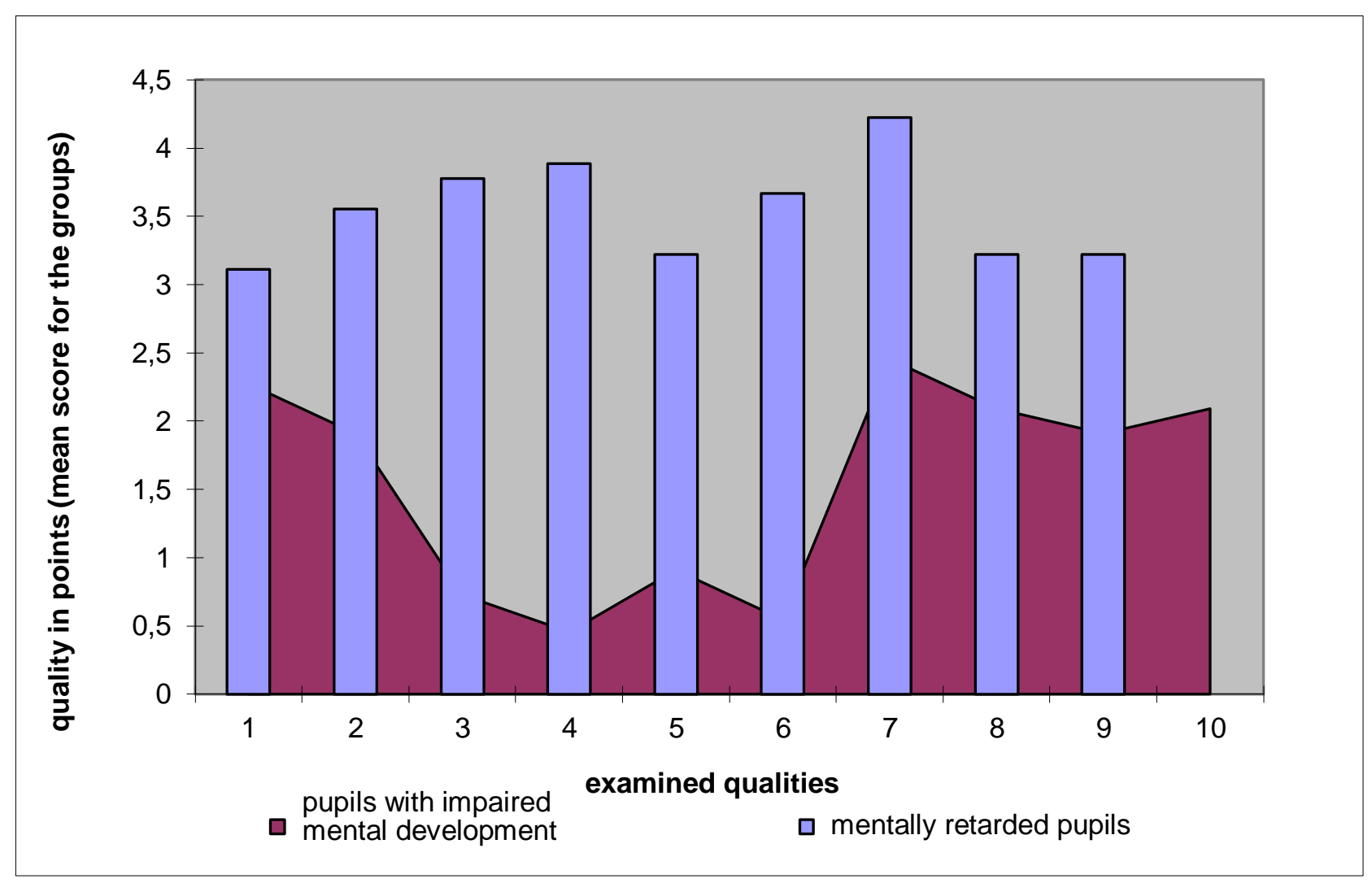

\section{Diagram 1. Comparative characteristic of behavioural qualities by observation results (Yu.Z. Gilbukh's table)}

The analyzed obtained data confirm that the pupils with impaired mental development, compared with mentally retarded pupils, have lower quantitative indicators for all studied criteria - attitude to difficulties, behaviour, stress in tasks performance, working capability. However, it should be noted that the special-need school pupils have a rather high level of sociability. 
At this stage, we also questioned the pupils in order to study their motivation for school attendance. According to the questionnaire results, pupils of the both samples were divided into two groups. The first group pupils show high interest in school attendance and have positive attitudes towards learning. The second group pupils show low or below average school motivation as evidenced by the data in Table 2 .

Table 2

Results of the school motivation study for the examined respondents

\begin{tabular}{|c|c|c|c|c|c|c|c|c|c|c|c|}
\hline \multirow[b]{2}{*}{ № } & \multirow{2}{*}{$\begin{array}{l}\text { Respondent } \\
\text { groups }\end{array}$} & \multicolumn{10}{|c|}{ Questions of the questionnaire } \\
\hline & & 1 & 2 & 3 & 4 & 5 & 6 & 7 & 8 & 9 & 10 \\
\hline 1. & $\begin{array}{c}\text { Pupils with } \\
\text { impaired mental } \\
\text { development } \\
n=36\end{array}$ & $\begin{array}{l}\text { J } \\
0 \\
\text { H } \\
\text { ? } \\
\text { i }\end{array}$ & $\begin{array}{l}5 \\
0 \\
0 \\
0 \\
0 \\
i\end{array}$ & $\begin{array}{l}\overrightarrow{0} \\
0 \\
+ \\
\hat{0} \\
\hat{0}\end{array}$ & $\begin{array}{l}0 \\
8 \\
H \\
\text { iv } \\
0\end{array}$ & $\begin{array}{l}0 \\
0 \\
0 \\
+1 \\
\infty \\
\sigma \\
0\end{array}$ & $\begin{array}{l}0 \\
0 \\
0 \\
+1 \\
0 \\
n \\
0\end{array}$ & \begin{tabular}{l}
8 \\
0 \\
0 \\
+1 \\
\multirow{2}{2}{} \\
i
\end{tabular} & $\begin{array}{l}2 \\
0 \\
0 \\
+1 \\
0 \\
0 \\
i\end{array}$ & $\begin{array}{l}2 \\
0 \\
0 \\
+1 \\
0 \\
\text { in }\end{array}$ & $\begin{array}{l}\text { t } \\
0 \\
+1 \\
\text { i }\end{array}$ \\
\hline 2. & $\begin{array}{l}\text { Pupils with } \\
\text { mental } \\
\text { retardation } \\
\mathrm{n}=32\end{array}$ & $\begin{array}{l}\hat{0} \\
0 \\
\text { H } \\
\text { ה } \\
\text { in }\end{array}$ & $\begin{array}{l}\text { ô } \\
0 \\
+ \\
\text { mे } \\
\text { nे } \\
i\end{array}$ & $\begin{array}{l}\overrightarrow{0} \\
0 \\
+1 \\
0 \\
i\end{array}$ & $\begin{array}{l}0 \\
0 \\
0 \\
+1 \\
0 \\
0 \\
-1\end{array}$ & \begin{tabular}{l}
0 \\
0 \\
+1 \\
\multirow{2}{*}{} \\
0
\end{tabular} & $\begin{array}{l}0 \\
0 \\
+ \\
+ \\
\infty \\
\infty \\
-\end{array}$ & 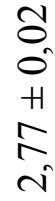 & $\begin{array}{l}0 \\
0 \\
+1 \\
m \\
m \\
m\end{array}$ & $\begin{array}{l}\text { on } \\
0 \\
+1 \\
+ \\
\text { m. } \\
\text { in }\end{array}$ & $\begin{array}{l}\text { Õ } \\
0 \\
\text { H } \\
\text { = } \\
\text { ci }\end{array}$ \\
\hline
\end{tabular}

As for the studied learning motivation, the data of special-need and general secondary school pupils were distributed as follows: (see Table 3).

Motivation for school attendance and learning motivation varies considerably between the pupils with impaired mental development and the examined secondary school pupils.

Table 3

Respondents' motivation

\begin{tabular}{|l|c|c|}
\hline \multirow{2}{*}{ Level of motivation } & \multicolumn{2}{|c|}{ Respondents } \\
\cline { 2 - 3 } & $\begin{array}{c}\text { Pupils with impaired } \\
\text { mental development, } \\
\mathrm{n}=36\end{array}$ & $\begin{array}{c}\text { Pupils with mental } \\
\text { retardation, } \mathrm{n}=32\end{array}$ \\
\hline High & - & $21,87 \%(7)$ \\
\hline Sufficient & $25 \%(9)$ & $56,25 \%(18)$ \\
\hline Average & $19,4 \%(7)$ & $21,87 \%(7)$ \\
\hline Below average & $36,11 \%(13)$ & - \\
\hline Low & $19,4 \%(7)$ & - \\
\hline
\end{tabular}


The questionnaire analysis has led us to answer to the question why pupils are willing to attend school. According to the obtained average data, pupils from both samples are happy to attend school, but the reasons for school attendance are different. The indicators of cognitive activity are particularly low at the pupils with impaired mental development.

The analyzed results show that cognitive activity as a motive for school attendance for the special-need school pupils is at the third place, after communicative and socially normative motives; that is, adolescents of this category have insufficient learning motivation, and school attendance for them has a purely communicative and emotional character. In addition, the influence of the external factor - school attendance control by teachers or parents - is very important.

The second stage of the experimental research consisted of the psychophysiological studies: strength and mobility of the pupils' nervous processes in accordance with E.P. Ilyin's method (tapping test) were investigated.

By calculation of quantitative data obtained by this method, we have constructed graphs of working capability of each pupil. The following results were obtained for the sample of the pupils with impaired mental development: 3 pupils (8.33\%) have the convex type of their nervous system, $6(16.7 \%)$ pupils have the descending one, 6 pupils have the intermediate one, 6 pupils have the concave type, 15 pupils $(41.6 \%)$ have the equal one.

Thus, most of the special-need school pupils have their nervous systems of equal and descending type, which correspond to the nervous system with an average and tendency to weak strength. This can explain weak attention and underdeveloped memory of the pupils with impaired mental development.

As for the mentally retarded pupils examined with E.P. Ilyin's method (tapping test) , 21 pupils (65.6\%) have the convex type of their nervous system, 4 pupils $(12.5 \%)$ have the convex and intermediate types, and 3 pupils $(9.4 \%)$ have the equal type. The analysis of individual data of the mentally retarded pupils show that most of them have a mixed type of nervous system, but as for their working capacity all pupils tend to have a strong or moderate nervous system. Only one pupil showed rather low working capacity and two pupils showed quick fatigue (a sharp decline in working capacity at the end of work). 
Taking into account the average data, we have constructed graphs of working capacity for both groups (Diagram 2).

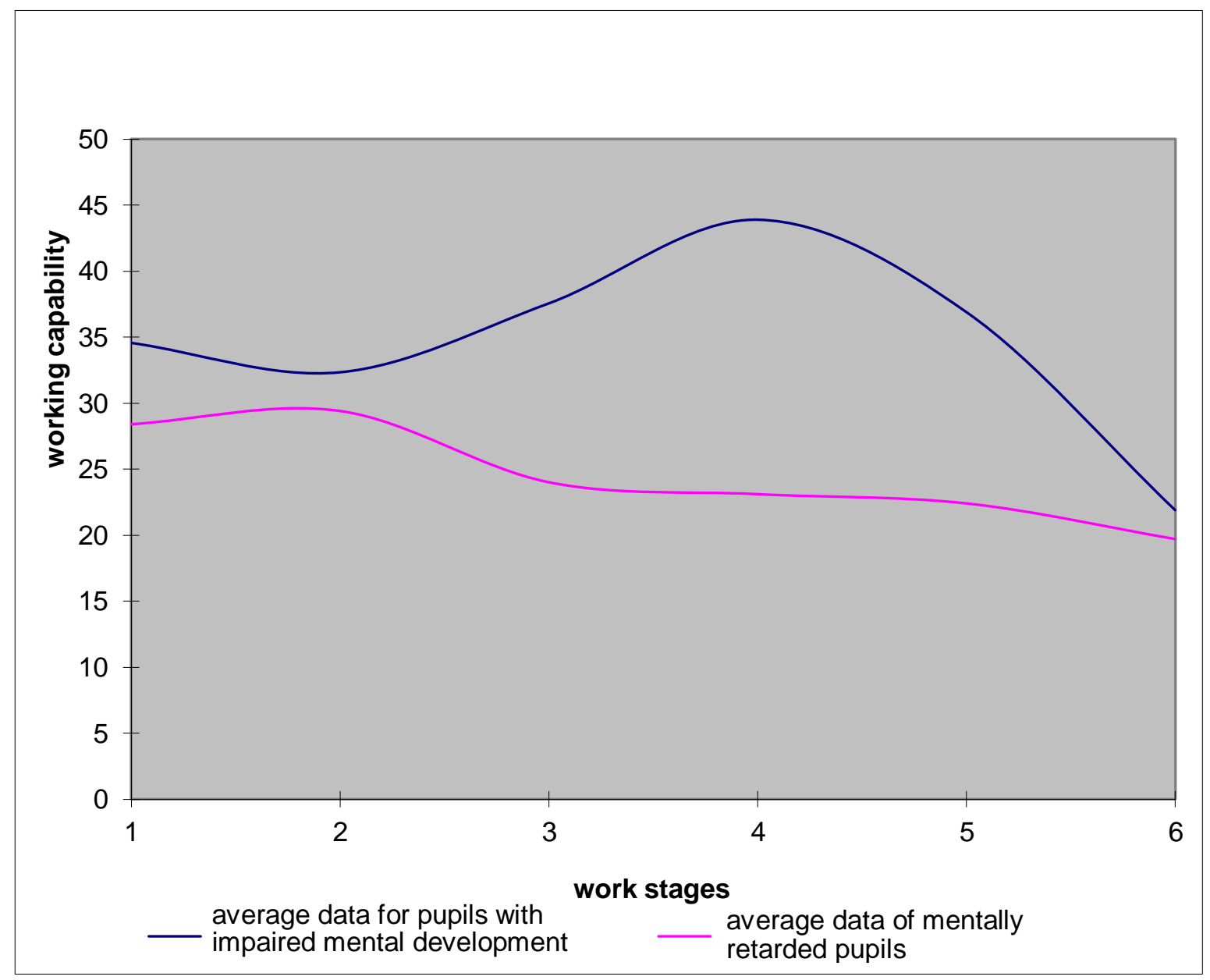

\section{Diagram 2. Comparative characteristics of the nervous process strength of the pupils with impaired mental development and the mentally retarded pupils by the tapping test}

According to the constructed graphs, the working capability graph of the pupils with impaired mental development shows the equal nerve processes, indicating the weak nervous system. Contrary, the working capability graph of the mentally retarded pupils shows tendency characteristic for convex nervous processes. This suggests that these pupils have the weak variation of strong nervous processes. But, given that at the task end the qualitative indicator dropped significantly lower of the initial level, we can argued that the vast majority of the mentally retarded pupils have the nervous system of average strength. 
The method of N.V. Makarenko, A.E. Khilchenko allowed us to determine not only types of the nervous system, but also the nervous process mobility to find out the pupils' general working-fatigue brain processes.

Table 4 was compiled with the obtained results; it reflects the fatigue factor for pupils form each group, the strength and mobility of their nervous processes. The higher the coefficient of fatigue is, the lower the mental working capacity is.

Table 4

Summary table of results (according to the method of N.V. Makarenko, A.E. Khilchenko)

\begin{tabular}{|c|c|c|c|c|c|c|c|c|}
\hline \multirow[b]{2}{*}{ № } & \multirow[b]{2}{*}{$\begin{array}{l}\text { Respondent } \\
\text { groups }\end{array}$} & \multirow{2}{*}{ 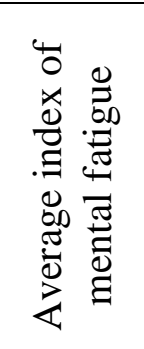 } & \multicolumn{3}{|c|}{$\begin{array}{l}\text { Strength of nervous } \\
\text { processes }\end{array}$} & \multicolumn{3}{|c|}{$\begin{array}{l}\text { Mobility of nervous } \\
\text { processes }\end{array}$} \\
\hline & & & 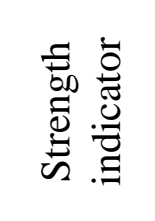 & 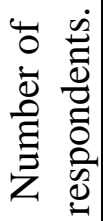 & 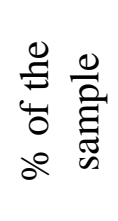 & d & 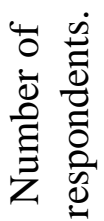 & 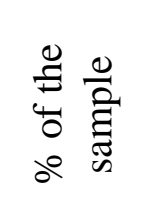 \\
\hline \multirow{3}{*}{1.} & \multirow{3}{*}{$\begin{array}{c}\text { pupils with } \\
\text { impaired mental } \\
\text { development } \\
n=36\end{array}$} & \multirow{3}{*}{$44,34 \%$} & Strong & - & - & low & 36 & $100 \%$ \\
\hline & & & Average & - & - & average & - & - \\
\hline & & & Weak & 36 & $100 \%$ & high & - & - \\
\hline \multirow{4}{*}{2.} & \multirow{4}{*}{$\begin{array}{l}\text { Pupils with } \\
\text { mental } \\
\text { retardation } \\
\mathrm{n}=32\end{array}$} & \multirow{4}{*}{$35,70 \%$} & Strong & - & - & low & 11 & $34,37 \%$ \\
\hline & & & \multirow[t]{2}{*}{ Average } & \multirow[t]{2}{*}{ - } & \multirow[t]{2}{*}{ - } & $\begin{array}{l}\text { Below } \\
\text { average }\end{array}$ & 21 & $65,63 \%$ \\
\hline & & & & & & average & - & - \\
\hline & & & Strong & 32 & $100 \%$ & high & - & - \\
\hline
\end{tabular}

The presented data testify that all the studied pupils from the experimental sample have low mental working capability, which explains quick fatigue of mentally retarded students and slow assimilation of new information by them. At such a level of mental fatigue, constant actuation of attention, repeated explaining and fixing of new material is necessary.

At the beginning of the work, the brains of all the respondents tried to adapt to the information speed, but after a threshold of 90 frames per minute, the brain fell into the state of protective inhibition, which explains approximately the same number of errors made bu all respondents. It should be noted that four pupils with impaired mental 
development could not achieve the optimal rate of nervous process mobility even at the minimal speed of visual information. In the course of the study, they could not overcome the permissible errors limit of $5.5 \%$, which indicates, in one case, a very low mental working capacity in general (this pupil has a brain tumour) on, in the others, pupils' impossibility to establishing fast links in their brains as a result of very slow attention switching and very low mobility of their nervous processes.

The average index of mental process fatigue in the experimental sample was $44.34 \%$.

At first glance, individual indicators of the pupils' mental fatigue were not very different. All pupils from both the control and experimental groups showed weak strength of their nervous processes. But, having analyzed the results of the mentally retarded pupils and taking into account their physical development, we see that the fatigue coefficient of the mentally retarded pupils tends with age to decrease, which, in our opinion, suggests development of their nervous processes. Most likely, this is due to the physiological characteristics of their nervous system. The average fatigue indicators of both samples differ for more than $10 \%$.

The data in Table 4 show the age dependence of the coefficient of fatigue, the older the mentally retarded pupils are, the longer they can maintain their ability to work, in contrast to the pupils with impaired mental development, for whom explicit dynamics is not observed. We think that this can be explained by the nervous system capability to selfregulation and development. In other words, the mentally retarded pupils have physiological opportunities to improve their neural processes, whereas this possibility of the pupils with impaired mental development is reduced.

As it was noted earlier, fatigue and working capacity are directly proportional; therefore, the Diagram 3 shows clearly how quickly does fatigue occurs at the pupils with impaired mental development, and how the nervous system adapts to the changes at the mentally retarded pupils.

At the special-need school pupils, fatigue develops from the very beginning of work and increases rapidly. The mentally retarded pupils' work is characterized by a short-term "familiarization with the tasks" and a short-term optimal working capacity. And only then there is a dynamic decline of mental working capacity of such pupils. In addition 
to quick fatigue, transition to protective inhibition of the special-need school pupils occurs earlier than that of the mentally retarded pupils. These differences can be explained by different mobility of their nervous processes.

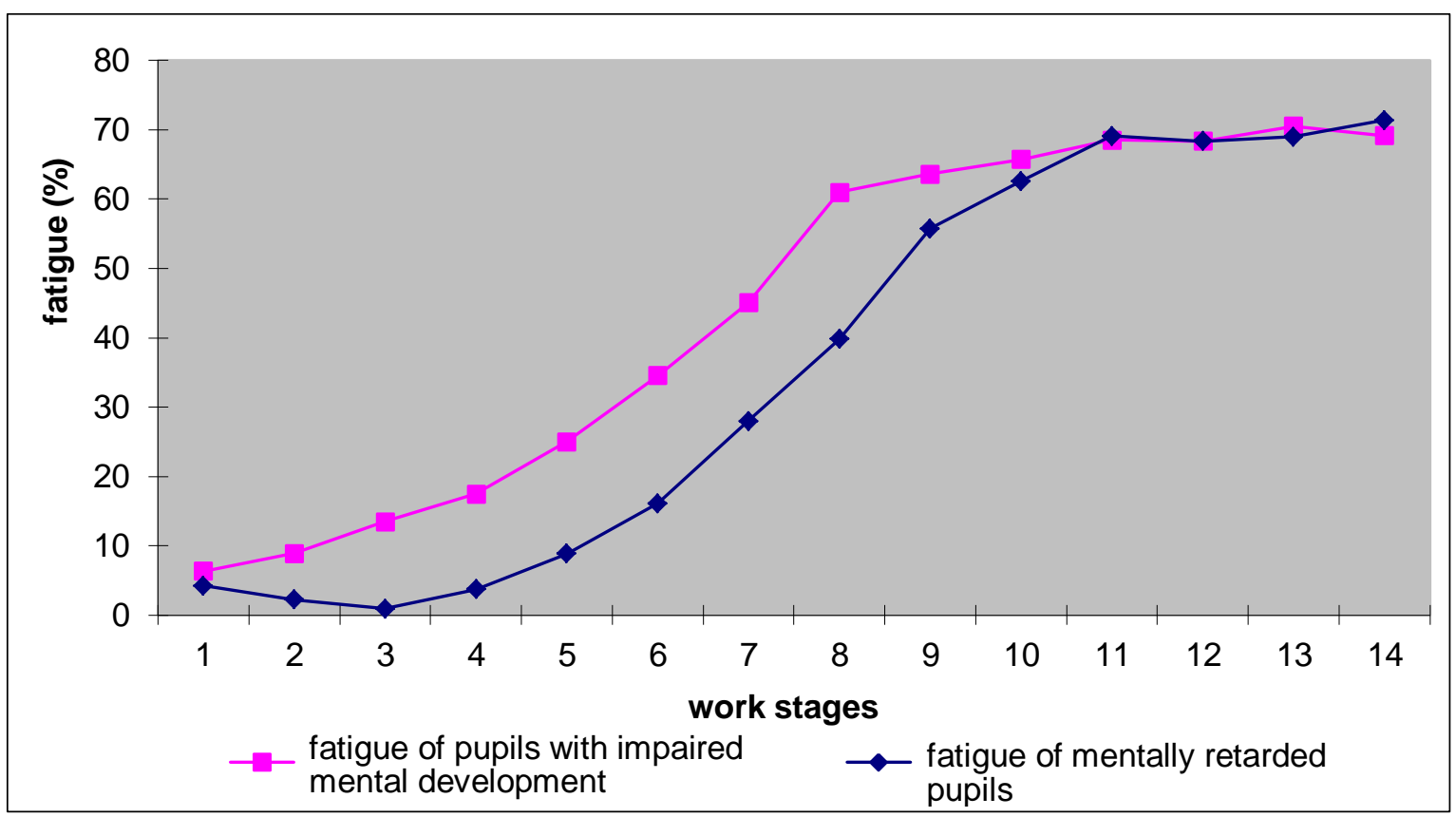

\section{Diagram 3. Comparative characteristic of fatigue of the pupils with impaired mental development and the mentally retarded pupils}

At the last stage of our experiment, we determined the processes of mental working capacity with the E.Krepelin's method (a modification of R. Schult's method) in order to identify fatigue and "workability".

The working capacity coefficient is calculated by the formula $\mathrm{K}=\mathrm{S} 1 / \mathrm{S} * 100 \%$ (where $\mathrm{K}$ is the working capacity coefficient, $\mathrm{S} 1$ is a number of correctly calculated examples in the last four lines of the form, $\mathrm{S}$ is a number of examples correctly calculated in the first four lines of the form. If the calculations result is close to $100 \%$, fatigue is practically absent, working capacity is high.

The analyzed obtained experimental data shows that among the special-need school pupils, 7 pupils (19.44\%) have high mental working capacity; 14 pupils (38.88\%) have sufficient working capacity; 7 pupils (19.44\%) have average working capacity; 3 pupils $(8.34 \%)$ have below average working capacity; 5 pupils (13.9\%) have low mental working capacity. 
7 pupils form this sample showed high results as for mental working capacity (by E.Krepelin's method), which does not exclude an error of the established diagnosis - impaired mental development. All examined parameters of these pupils correspond to mental retardation.

The overall coefficient of mental working capacity in the control group does not differ much from that of the experimental group. The data was distributed as follows: 4 pupils (12.5\% of the total sample) showed high mental working capacity; 24 pupils (75\%) showed above average mental working capacity; and 4 pupils showed average mental working capacity (Table 5).

At first glance, we obtained very high indicators of mental working capacity, but at result analyze, it is necessary to take into account the quality of work performed.

Table 5

Results of the respondents' work ability research by E.Krepelin's method

\begin{tabular}{|c|c|c|c|c|c|}
\hline \multirow{2}{*}{$№$} & Respondent groups & \multicolumn{2}{|c|}{$\begin{array}{c}\text { number of } \\
\text { correct } \\
\text { answers }\end{array}$} & \multicolumn{2}{|c|}{$\begin{array}{c}\text { overall coefficient of mental } \\
\text { working capacity }\end{array}$} \\
\cline { 3 - 6 } & $\mathrm{S}$ & $\mathrm{S} 1$ & average & $\%$ \\
\hline 1. & $\begin{array}{c}\text { Pupils with impaired } \\
\text { mental development } \\
\mathrm{n}=36\end{array}$ & 22 & 16,1 & 0,73 & $73 \%$ \\
\hline 2. & $\begin{array}{c}\text { Pupils with mental } \\
\text { retardation } \mathrm{n}=32\end{array}$ & 29,6 & 23,3 & 0,78 & $78 \%$ \\
\hline
\end{tabular}

Only $36.1 \%$ (13 persons) of the studied pupils with impaired mental development performed task satisfactory, and $63.9 \%$ of them ( 23 persons) performed the task with very low quality at the appointed time. The analysis of overall indicators of the performed tasks shows that the task quality shown by the pupils with impaired mental development significantly differs from that of the pupils with mental retardation. Therefore, despite almost the same coefficient of mental working capacity in the both samples, we cannot talk about the equal mental working capacity of the both groups. 


\section{CONCLUSIONS}

Summarizing all the above, we can make the following conclusions:

1. All pupils with impaired mental development showed lower mobility of their nervous processes compared with the data of the pupils with mental retardation.

2. The average coefficient of mental working capacity of the special-need school pupils, obtained by E. Krepelin's method, should be evaluated with taking into account quality of the completed tasks.

3 . The results of the examination of mental working capacity and fatigue of some pupils with impaired mental development are not consistent. These differences can be explained by the fact that the studied pupils were not homogeneous as for their disorders, intellectual abilities and learning achievements, but all respondents with intellectual disabilities had weak strength and low mobility of their nervous processes, that is, inhibition predominates over excitation.

4. Some pupils are characterized by renewal of mental working capacity after long-term inhibition of nerve processes, but all studied pupils from the special-need school are characterized by 2-3 time decline of working capacity after the initial rather high working capacity. This state of mental working capacity is maintained during subsequent work stages (with slight fluctuations);

\section{SUMMARY}

The article presents the research on psychophysiological features of middle-school age pupils with impaired mental development. The need to study the functional characteristics of such adolescents is stipulated by changes that take place at the puberty period and, therefore, such pupils' body ability regarding mental load and working capabilities. The performed experimental study showed that in the majority of the pupils with impaired mental development are characterised by weak strength and low mobility of their neural processes, whereas similar age pupils with mental retardation have weak strength but show slightly higher mobility of their nerve processes. The experimental results have showed the age dependence of the fatigue coefficient and workability duration, which is explained by the nervous system capability to self-regulation and development. Mobility of nerve processes of the pupils with impaired mental development remains low, so special organization of 
educational processed is required to increase their mental working capability.

\section{REFERENCES}

1. Занков Л.В. Обучение и развитие. Москва: Педагогика, 1975. 143 c.

2. Лурия А.Р. Высшие корковые функции человека. СанктПетербург, 2008. 624 с.

3. Макаренко М.В., Лизогуб В.С. Онтогенез психологічних функцій людини. Черкаси: Верикаль, видавець ПП Кандич С.Г., 2011. 256 c.

4. Микадзе Ю.В. Нейропсихология детского возраста : учеб. пособ. Санкт-Петербург, 2008. 288 с.

5. Павлов И.П. Общие типы высшей нервной деятельности животных и человека. Полное собрание сочинений. Академия наук СССР. 2-е изд., доп. Москва: Л. : Изд-во АН СССР, 1951. Т. 3, кн. 2. C. 267-293.

6. Певзнер М.С., Лубовський В.І. Динаміка розвитку дітей олігофренів. //Спеціальна психологія. Тексти. Ч. 1. Кам'янецьПодільський, 1999.-с. 36-54

7. Петрів О.П. Психологічні особливості розумової працездатності молодших школярів : дис. ... канд.психол. наук : 19.00.07. Київ, 2005. 238 с.

8. Синев В.Н. Коррекция интеллектуальных нарушений у учащихся вспомогательной школы : автореф. дис. ... докт. пед. наук : 13.00.03. $1988.45 \mathrm{c}$.

9. Яковлева С.Д. Нейрофизиологические основы деятельности детей с интеллектуальными отклонениями в развитии. Современное направление теоретических и прикладных исследований 2014 : сб. науч. трудов SWorld. 2014. Том 15. C. 84-93.

\section{Information about the author: Yakovleva S. D.}

Doctor in Psychological Sciences, Professor of the Department of Correctional Education Kherson State University 27, Universytetska str., Kherson, 73003, Ukraine 